\title{
Christian Scriptures and the Formation of Intellectual Humility
}

Professor Grant Macaskill, Kirby Laing Chair of New Testament Exegesis, University of Aberdeen

To date, the scholarly discussion of intellectual humility has paid little attention to the role played by sacred scriptures in the formation and development of that quality in communities of faith. Even where contributions have been theological in character, the normative role of scripture - however this may be conceived - has been discussed only marginally, with the focus instead being on the contributions of later theologians, such as Augustine or Aquinas. My own forthcoming study, The New Testament and Intellectual Humility (Macaskill, 2019), ${ }^{1}$ is unusual in this regard, being dedicated specifically to the function of the New Testament (operating within the broader canon of Scripture) in the formation of intellectual humility within Christian communities and the individuals who comprise them. My intention in this article is to reflect on some of the ways in which the findings of that study differ from the general discussion or debate around intellectual humility. These differences are probably somewhat baffling to many involved in the scholarly discussion, to the extent that they appear to involve issues entirely different to the ones normally discussed, but they are quite intelligible in the context of a functionally theological study of the Bible. The challenge of relating these findings to the wider discussion highlights the extent to which that discussion has abstracted the concept of intellectual humility from the realities with which it is enmeshed and by which it is defined in communities of faith.

\section{Textuality and Identity, Lexicon and Grammar: The Way the Words Run}

Even if the concept of 'authority' or 'normativity' is attached to the Bible in different ways by different traditions, most Christian communities would consider it to be a body of writing that distinctively shapes, resources and controls Christian thought and

1 This monograph will be the output of my funded involvement with the John Templeton Foundation-St Louis University project, The Philosophy and Theology of Intellectual Humility. I am grateful to the funders for their generous support. 
practice in a way that is not true of any other writings. It will be read, discussed, quoted and considered in ways that functionally set it apart from other sources of theology or ethics. The label 'Scripture', often capitalized, marks its distinctive functional significance in the lives of Christians and their communities.

The normative function of Scripture for Christian theology, however, must be understood in terms defined by its formal character. Scripture 'norms' Christian thought and practice, not as a treatise or propositional document, but as an apparently untidy collection of narratives, proverbs, parables, poems, hymns, prophecies, contracts and (in a smaller proportion than often recognized) laws. Indeed, the generic boundaries between these categories are rather permeable, with legal content embedded in narratives, narratives expressed in songs, parables and proverbs delivered in gospels, and so on. Theological tradition has always recognized the need to give orderly accounts of what we find in Scripture, but these accounts do not displace or replace the unruly collection of Scripture itself. One of the pitfalls facing theologians, and readers or hearers in general, is the risk of allowing one of the generic forms found within the biblical collection to become dominant over our systematic account: for some, the commandments (or, more abstractly, the concepts of 'command' or 'law') dominate; for others, narrative plays such a role, particularly a grand narrative that moves from genesis to palingenesis. ${ }^{2}$ A proper account of scriptural normativity, however, is attentive to its generic complexity and will allow this to define its operation. We encounter 'the word of God' as much in a proverb or poem as we do in the Decalogue.

As a generically complex collection, Scripture shapes the thought of its readers and hearers $^{3}$ by means of language acts. Particular words are used, with particular grammatical constructions. Biblical scholars are attentive to the original languages because subtle features of lexical choice and grammar can be lost in translation, or can be highlighted by the translational processes associated with the biblical manuscripts

\footnotetext{
${ }^{2}$ On this point, see Kevin Vanhoozer, First Theology (Downers Grove: Intervarsity Press, 2002), 151-4.

${ }^{3}$ It is easy to forget that widespread literacy is a fairly recent phenomenon. Most popular encounter with Scripture through the centuries has taken place through hearing.
} 
themselves, such as in the translation of Hebrew or Aramaic into Greek. ${ }^{4}$ Importantly, these language acts can sometimes be surprising or even jarring and this is precisely how they work to shape our cognition: we hear something we do not expect, and our mind changes in response.

For the discussion of intellectual humility, this proves to be quite significant. Particular word groups are used to denote humility in general and, at specific points, these are connected to the representation of good and bad thinking. In Hebrew, the principle word group centres on the verb 'anah (ענה) and the cognate substantive 'anaw, with its plural 'anawim (ענוים, ענו). The word group etymologically designates poverty, with 'anawim often occurring not just in the Bible but also in Second Temple Jewish literature to designate 'the poor'. Two further verbs are also encountered at points, shachach (שחח), meaning 'to bow down' and shaphal (שפל), meaning 'to be low'. The Hebrew vocabulary, then, is very particularly associated with issues of status or position: to be humble is to be 'poor' or 'low'. To recognize this is not to make the error of confusing distant etymology with contemporary usage: there are points in the text of the Old Testament where each of the words is used with its original significance, something reflected in Greek translations, which use multiple different words to render the significance of the 'ana-group, sometimes favouring the vocabulary of humility (tapeinos, tapeino $\bar{o}$, praus, et cetera), but sometimes the terminology of poverty (penēs). This is a similar situation to the one English speakers face when they use the 'poor': it may label a condition of financial deprivation, or it may label something that elicits sympathy. The critical point for the biblical material is that the association of these words with low status is retained.

Importantly, this positional element is represented in positive terms when it is defined relationally with respect to God. This positivity is, in fact, the first surprising twist we encounter in how the language of humility is deployed in the Bible. It is widely recognized that the positive view of humility found in the Jewish and Christian

\footnotetext{
${ }^{4}$ Biblical scholars recognise the distinctive place of translations of the Hebrew and Aramaic texts of the Old Testament into Greek, often designated (questionably) the Septuagint or LXX. Quotations of the Old Testament in the New reflect the use of such translations, possibly alongside Hebrew or Aramaic texts. The terms Old and New Testament are, of course, distinctively Christian labels for these scriptures.
} 
traditions was an oddity in the ancient world and the explanation is connected to the details of monotheism, as reflected in the Shema:

The LORD our God, the LORD is one. Love the LORD your God with all your heart and with all your soul and with all your strength. (Deut 6:4-5, NIV)

It is not intrinsically a good thing to be poor, but to be in a position of acknowledged poverty in relation to God is good, for it involves a recognition of dependency upon him; similarly, the acknowledgement that we are 'low' before God recognizes the need to submit to his rule. The narrative around the Shema, the whole story of the Exodus and subsequent wilderness sojourn, brings out both dimensions, as the Israelites rely upon divine care and provision and learn to submit to his rule, even if imperfectly. Both of these dimensions entail a recognition that we are not autonomous, and that our relationship to the world of things around us is not an autonomous one: we are dependent upon God as creator and providential caregiver, and we are subject to his reign. When this is related to the various passages that speak of God's role in the life of the cosmos (e.g., Job 38-41, with its descriptions of God's creative work and the intimacy of his involvement in providing and caring for the world and its constituents) we begin to see humility as a term that labels what it means to live rightly in God's world, interacting with the things around us as realities invested with God's care, rather than simply as commodities that we can possess and deploy as if they (and we, as acting subjects) are isolable objects.

The verbs are used in ways that highlight that humility is not an instinctive quality, or even one that is formed naturally, but rather a condition occupied by a decision or intervention that disrupts the native condition of non-humility. Commonly, the verb is found in reflexive form: people are expected to 'humble themselves' or are castigated for their failure to do so, while others are humbled by God. Those who fail to humble themselves are sometimes described as 'stiff-necked', an agricultural label that indicates their refusal to yield to the steering hand of the LORD. In fact, the existence of verbs of humility is itself an interesting defining feature of the concept: humility is the condition that obtains in those who have humbled themselves or been humbled, while pride is the condition that obtains in those who have not practiced this verb.

This also means that a cluster of qualities are often related to the practicing of humility. Those who are openly dependent upon God are characterised by gratitude and 
by hope, often manifest as a learned willingness to be patient for his provision. Those who yield to his rule limit their conduct according to his commandments; they wait upon God faithfully.

If this language defines humility as a general concept, it is also what defines its specifically intellectual instantiations. There is no point in the Scriptural material where something is called 'intellectual humility' that corresponds to the modern concept. The closest we come to this is the word tapeinophrosune in Philippians 2:3, which broadly means 'humility of mind/wisdom'. I will return to this in the next section, for the word is used in association with the incarnational reality, but at this point the key to note is that it designates a particular cognitive manifestation of the general concept of humility, something highlighted by the following statement:

Let the same mind be in you that was in Christ Jesus, who, though he was in the form of God, did not regard equality with God as something to be exploited (Phil 2:5, NRSV).

Instead, what we find in Scripture is a host of ways in which the one who is humble thinks in ways that are shaped by dependency and submission upon God, while the one who is proud thinks in ways that are not. This, in turn, impacts on the way that things are known and the kinds of perceptions that are attached to them. This "knowing" is not simply about comprehending an object properly, but about properly relating to it, interacting with it in a way that is fitting. Things cannot be known properly in isolation, but must be known in terms of the divine economy. Hence, the great statement of enlightenment in the Wisdom tradition: 'The fear of the LORD is the beginning of wisdom.'

While the language of humility is nowhere found in the description of the Fall in Genesis 3, the account can be read in such terms, in light of their broader biblical usage, with obvious cognitive overtones. The serpent seeks to disrupt the submission of Adam and Eve to the divine command, and does so by challenging the nature of their dependency upon God's provision. If they will eat this forbidden fruit, then they will become like gods themselves, 'knowing good from evil'. The parallels with the Prometheus myth are obvious and often mentioned, but contextually what is significant is that it is the characteristics that will later be associated with the vocabulary of 
humility that the serpent targets. Its strategy, moreover, is one that centres on the undermining of gratitude for the provision of all the other fruits. The paradigmatic sin, then, is one that involves a failure to sustain humility. Humility is part of what is lost at the Fall, and with it understanding. If 'the fear of the LORD is the beginning of wisdom' then this sin is the beginning of folly. Here, the truth of God is exchanged for a lie: 'they became futile in their thinking, and their senseless minds were darkened' (Rom 1:21). There is a word for this in Scripture: idolatry. The writers of the biblical texts, particularly those of the New Testament, see this idolatry precisely as a force that distorts knowledge and that is exposed by divine activity (1 Cor 1:18-21). Pride is a correlate of this, because it involves a perception that one is self-sufficient, whether in terms of acquiring goods to sustain and enrich oneself, or in terms of differentiating good and evil. The proud person sees no need to be grateful for their daily bread, or to yield their sense of right and wrong to the commandments of God.

There are undoubtedly some parallels between this basic lexicon and grammar of humility and the concepts of intellectual humility that mark the scholarly study. Most obviously, the lexicon points to humility as something defined in terms of position or status, which sounds rather like the 'low concern for status' approach (cf. Roberts and Wood, 2007). In the acknowledgement of dependency upon God, it also suggests something of an ownership of limits (cf. Whitcomb, et al., 2015). In the confidence it can have in its knowledge, when this is contextualised by proper relationship with God - its confidence to state that the fear of the LORD is the beginning of wisdom - it echoes the doxastic (Church and Samuelson, 2017). But in each of these cases, it is very distinctively shaped with reference to God and the covenant that defines his relationship with the redeemed. It is particularised by these things, and an element of the particularity is that humility is as strongly associated with the volitional dimension of cognition as the epistemic. To think humbly is not just a condition for the right knowledge of things, but a condition for the right decisions of how to live. To be intellectually humble is not just a matter of epistemic rightness, but of volitional righteousness.

This last statement anticipates something that will run through the rest of the article. If the biblical material leads its readers to the conclusion that 'there is no-one righteous, not even one' (Rom 3:10, quoting Pss 14:1 and 15:1), then how might any of us be expected to attain a state of intellectual humility, such that we will both know and decide righteously? For the New Testament writers, the answer (however variously expressed) 
lies in the incarnation of Jesus Christ and the accompanying work of the Spirit to renew minds after his likeness.

\section{The Way the Words Run around the Word Made Flesh.}

We have already seen a surprising twist in the way that the lexicon of humility is used in the Bible, when compared to other examples of ancient thought: humility is represented in positive terms. The twist is intensified and progressed in the New Testament, and subsequently in Christian theology, by the association of the concept with the object of worship himself. At key points, Jesus Christ is represented as humble and those points happen also to involve some of the clearest and most forceful articulations of his identification as God. We have already mentioned one of these passages, Philippians 2:1-11. Here, Paul's addressees are enjoined to 'think' (phroneite) within themselves in the same way that Christ did (2:5), with this corresponding to the 'humility of mind' (tapienophrosunē) that is called for in verse 3. Importantly, the humility of mind is manifest in a commitment to pursuing the good of others, and not simply of oneself; that is, it is identified with acts of love, by which the good of others is given a higher priority than one's own interests or prerogatives, sometimes demanding that those prerogatives are set aside. This is exemplified by the incarnational story itself, within which the one who is 'in the form of God' divests himself of the privileges ${ }^{5}$ associated with his divine status and takes the form of a servant or slave (doulos), in order to bring about salvation. Importantly, the 'humility of mind' is not something that is brought about by the taking of a lowly form, an acknowledgement of the limitations that characterize this state, but is the thing that leads to and makes possible this taking. Because the one in the form of God is humble,

\footnotetext{
${ }^{5}$ The question of what, precisely, is indicated by the use of the verb kenoo has been widely explored. The cognate noun, kenosis, is not used in the text, but has been associated with 'kenotic christologies' which consider the Son to have given up some of the attributes of divinity in the incarnation. For our purposes, we can largely ignore these christologies (which are, in fact, shaped more by the accounts of the gospels than by Philippians 2), since what matters here is that the humility in question causes the incarnation, rather than resulting from it.
} 
he takes the form of a servant. The humility here is a quality of one who is identified with the plenitude and perfection of God himself.

In certain regards, this is consistent with the 'low concern for status' definition, but its significance is richer because of the sheer qualitative distance between the status of deity and doulos ("servant" or "slave"). The passage, moreover, makes clear that the one who has undertaken this act of self-divestment will subsequently be the object of praise and honor (2:9-11), so that there is not so much a low concern for status - there is actually a very high concern for this, linked to the expectation of proper worshipbut rather a commitment to serving the needs of others. For this reason (and out of a recognition of the driving significance of Isaiah's Fourth Servant song for the representation of Jesus in Philippians 2), my own approach to the passage has centred on the concept of 'servanthood'. The one who is humble serves; tapeinophrosunē labels how such a one thinks.

In Matthew 11:25-31, we encounter another dramatic example of the association of humility with the one who is incarnate. Using language often seen as reminiscent of that used of (or by) Wisdom herself in the biblical and postbiblical material, Jesus says

28 "Come to me, all you that are weary and are carrying heavy burdens, and I will give you rest. ${ }^{29}$ Take my yoke upon you, and learn from me; for I am gentle and humble in heart, and you will find rest for your souls.

In fact, we have two of the words used as Greek translations for the Hebrew anaw- : tapeinos and praus, the latter translated here as 'gentle'. Contextually, the words are interesting for several reasons. The first is that Jesus' interactions with his interlocutors hardly evince an open-mindedness of the kind often associated with intellectual humility. Quite the opposite, Jesus begins to 'reproach' or 'denounce' (oneidizein) those who have failed to understand the significance of his ministry and have not repented. He goes on to associate this with the hiddenness of these truths ('these things', 11:25) to 'the wise and intelligent', and their disclosure to 'infants' (nēpioi). This leads to the second reason that the language of humility here is interesting, which is that it is used in connection with some very lofty claims to knowledge: 
All things have been handed over to me by my Father; and no one knows the Son except the Father, and no one knows the Father except the Son and anyone to whom the Son chooses to reveal him (Matt 11:27, NRSV).

There is here no ownership of limits or acknowledgement of bias. We might, in fact, consider this a very dramatic articulation of Jesus' humility, understood in doxastic terms; without culpability, he can claim to know the Father in a unique way, and to have custody of 'all things'. But the loftiness of his claim to knowledge is given its point by the coordination of these two words for humility-tapeinos and praus - that indicate he will make himself present and accessible to those who are impoverished. Those who are weary and heavy laden are exhorted to 'come' to him. That this exhortation immediately follows his statement concerning the Son's freedom to reveal the Father to whomever he chooses is important: to 'come' to the Son and find rest is to be the recipient of this disclosure. And the disclosure, crucially, is one constituted by personal presence. As Pardue notes, this is an element traceable back into the representation of God in the Old Testament: even in his lofty exaltation, God is a friend to the poor, the widow and the orphan, and makes himself present with them. Presence is, moreover, a prominent theme in Matthew's Gospel: Jesus is announced with the name Emmanuel, God with Us, in 1:23 and following his resurrection promises to be 'with' his disciples to the end of the age (28:20). Here, though, this emphasis on presence is distinctively associated with the disclosure of knowledge: those in the presence of the humble and gentle one know the Son, and by knowing the Son they know the Father.

Readers or hearers of the New Testament, then, find their understanding of 'humility', and its manifestation in their intellectual lives, to be developed in surprising ways by the incarnational narratives. First, the language of humility can be attached to God himself, as something that labels his willingness to serve those who have no capacity to return his gift $^{6}$ and, as such, something associated with plenitude and

\footnotetext{
${ }^{6}$ The point has been made recently by Barclay, 2015 that Paul's representation of the divine gift needs to be set against the background of ancient gift-giving, which was a kind of economic practice that expected some kind of return from the one to whom a gift was given. The radical quality of God's gift is that, unlike other such gifts, it is made to those who are incapable of return.
} 
freedom, not deficiency or limitation. This aspect of humility's semantic range is linked to the "positional" quality of the language: God does not remain aloof from the impoverished but lowers himself to be with them, and his doing so is an act of strength, not weakness. Second, and flowing from this, the language is connected with the volitional dimension of cognition: the one who is humble chooses to act in a way that disregards matters of status or honor. Third, there is an epistemic dimension, but it is connected to a particular kind of knowledge that can be known only by personal presence and interpersonal disclosure: we can know God, only because he makes himself accessible to us through the Son. This makes the knowledge of God something in which there is no grounds for boasting: we have not 'achieved' such knowledge, ${ }^{7}$ but have been given it.

\section{The Spirit and the Renewal of the Mind: Can We Really Speak of 'Virtue'?}

Humility, then, is given a particular and complex ${ }^{8}$ significance by the biblical material, one that is represented as having implications for how we think. The lexicon of humility, the grammar with which it is used, and the deployment of these in relation to the incarnational narrative leaves us with a sense of what it means 'to think humbly' that is somewhat different from much of the discussion of intellectual humility. This is not a criticism of the scholarship, but simply an acknowledgement that intellectual humility is always particularised within religious communities by their sacred

\footnotetext{
${ }^{7}$ Cf. Greco, 2010.

${ }^{8}$ By this, I mean that the vocabulary of humility is not reducible to a single discrete concept but involves a set of inter-related values and dispositions associated with both creatures and their Creator. For creatures, particularly for sentient ones, humility involves dependency upon God and submission to his rule. It also involves an acknowledgement of the power of sin and idolatry to disrupt or distort this basic relationship. For God, humility involves a willingness to stoop or to condescend, in order to bring blessing to the lowly. Both of these meanings emerge from the basic lexical association of humility with lowness or poverty. When God assumes a creaturely nature in the incarnation, or when creatures participate in the divine life through the incarnation, the divine and human elements of humility can co-exist.
} 
scriptures, as works of language. This needs to be part of the consideration of intellectual humility, particularly as a practical theological topic.

One further issue must now be considered. We noted that humility is not an intuitive or native thing for humans, nor one principally represented as being acquired through gradual formation: instead it is linked to deliberate acts of humbling ourselves or being humbled by God, so that we occupy a proper relationship with him, one of dependency and submission. Within the New Testament, such ideas of reflexive transformation (doing something to ourselves) or divine disruption (where God does something within us) become particularised around believers' union with Christ, realised by the operation of the Holy Spirit. This is, perhaps, most dramatically seen in Paul's writings, and Romans 8:5-11 is as good a passage as any to illustrate the point, especially as it bears on the mind:

${ }^{5}$ For those who live according to the flesh set their minds on the things of the flesh, but those who live according to the Spirit set their minds on the things of the Spirit. ${ }^{6}$ To set the mind on the flesh is death, but to set the mind on the Spirit is life and peace.

9 But you are not in the flesh; you are in the Spirit, since the Spirit of God dwells in you. Anyone who does not have the Spirit of Christ does not belong to him. ${ }^{10}$ But if Christ is in you, though the body is dead because of sin, the Spirit is life because of righteousness. ${ }^{11}$ If the Spirit of him who raised Jesus from the dead dwells in you, he who raised Christ from the dead will give life to your mortal bodies also through his Spirit that dwells in you.

What emerges from the wider body of Paul's writing, with parallels elsewhere in the New Testament, ${ }^{9}$ is that this 'Christopneumatic' ${ }^{10}$ core to Christian cognitive agency drills down into our very sense of self-hood and identity, and does so in a highly disruptive way. Again, Paul gives the starkest articulation of this sense of disruption:

\footnotetext{
${ }^{9}$ Most notably, the representation of new birth in John 3:7 or 1 Pet 1:3.

${ }^{10}$ This term is sometimes used in connection with historical theologies (particularly of the sacraments) that have recognised the combination of Christological and pneumatological elements. See, e.g., Chauvet, 1995, 252.
} 
I have been crucified with Christ and it is no longer I who lives, but Christ lives in me (Gal 2:19-20, NRSV).

This basic disruption to Paul's sense of who he is as a moral or cognitive agent results in a radical openness to new ways of thinking:

From now on, therefore, we regard no one from a human point of view (literally, 'according to flesh' kata sarka); even though we once knew Christ from a human point of view, we know him no longer in that way. (2 Cor 5:16, NRSV)

Yet whatever gains I had, these I have come to regard (hègēmai) as loss because of Christ (Phil 3:7)

Paul has come to occupy a different set of opinions and beliefs, because of the disruption of his stable sense of identity, through what he perceives to be the work of the Spirit. His mind has been opened to new evaluations, and his old way of thinkingincluding his religious beliefs- he now sees as corrupted by the instincts of his flesh.

For Paul, of course, this disruption can be traced back to his encounter with the risen Jesus on the road to Damascus; there, he was confronted by God and humbled. He extends this disruptive language to all believers, however:

So if anyone is in Christ, there is a new creation: everything old has passed away; see, everything has become new (2 Cor 5:17, NRSV).

Furthermore, the imagery of new identity in Christ is often used reflexively, using the language of clothing:

As many of you as were baptized into Christ have clothed yourselves with Christ (Gal 3:27, NRSV)

Put on the Lord Jesus Christ, and make no provision for the flesh, to gratify its desires (Rom 13:14, NRSV) 
As an equivalent to the language of humbling oneself, then, we find the language of clothing oneself with another. The noetic significance of this emerges in Ephesians 4 and Colossians 3

${ }^{22}$ You were taught to put away your former way of life, your old self, corrupt and deluded by its lusts, ${ }^{23}$ and to be renewed in the spirit of your minds, ${ }^{24}$ and to clothe yourselves with the new self, created according to the likeness of God in true righteousness and holiness. (Eph 4:22-24, NRSV)

${ }^{9}$ Do not lie to one another, seeing that you have stripped off the old self with its practices ${ }^{10}$ and have clothed yourselves with the new self, which is being renewed in knowledge according to the image of its creator. (Col 3:9-10, NRSV)

The intellectual transformation of believers, then, is not simply associated with some personal moral progress or formation, but with a perceived re-mapping of their identity onto that of another person, with whom they have clothed themselves.

I stress this because it lay at the heart of the critique of much virtue theory by the early Reformers, and remains a necessary part of any account of moral identity that seeks to take the New Testament witness seriously. This means that any talk of 'virtue' is immediately qualified, and continues to be used only in a qualified way: the development of intellectual humility (as represented in the New Testament) is not the result of the progress and development of the individual person through processes of personal formation, but is a result of that person being demolished and remade in union with someone else. To put this slightly differently, the intellectual humility that might come to mark a believer is not something that grows out of the nurturing of who they are, but out of the presence in them of someone else. It is because the one who says 'I am humble and gentle in spirit' resides in them that they can be humble themselves. ${ }^{11}$

${ }^{11}$ This should not remove the notions of formation and discipline from accounts of Christian life, but it does require them to be conceived carefully with respect to the person of Jesus Christ. I examine this in greater depth in my forthcoming book, Paul's Ethics of Participation: Union with Christ and the Christian Moral Life (Grand Rapids: 
The point underpins a further observation, which is that the reflexive act of clothing ourselves with Christ is not represented as a comfortably complete work, but as an ongoing and difficult obligation of Christian life, taking place in constant tension with the persistence of $\sin$ in the lives of believers and their communities. This is important, for it serves to explain and acknowledge something that may occur to readers: Christians are not necessary intellectually humble. While this statement may reflect cultural assumptions about what humility involves that ought to be called into question-Jesus, we have already noted, was humble in a rather abrasive way! — it also rightly recognises the continuing presence of arrogance within the communities of the church. This should be called out and exposed, but our account gives us a category within which to place such arrogance properly: it is a sign of sin's persistence, a witness to the incompleteness of sanctification in the lives of believers, which can only be addressed by the disruptive presence of the Spirit of Christ.

\section{Conclusions}

My intention for this article has not been to resolve any of the debates around intellectual humility, or to suggest that there is anything superior about how the concept might be informed by the New Testament. Rather, my point has been to call attention to some of the ways in which the concept is particularised within faith communities that cherish the biblical material as sacred scripture, for whom it is normative. There is, of course, a significant overlap between the scriptures of Judaism and Christianity, but also a difference in the eventual shape that the canon will take for each. Both traditions operate with concepts of humility that bear on one's cognitive life, which are shaped by these texts, whether read or heard through the reading of others. As such, intellectual humility is distinctively defined by the words used and the way these words run, that is, by the lexicon and the grammar of humility. For the Christian tradition, the application of the lexical and grammatical elements to the story of Jesus becomes pivotal to how intellectual humility is conceived.

Obviously, I have only been able to isolate some of the major elements that are important in the development of the concept in the New Testament; I consider much more of the detail in my forthcoming monograph on the topic. I have also done little

Baker, 2019), which involves extensive reflection on how Christian moral identity can be nourished. 
here to consider how the process of reading or hearing this material might change the cognitive state or disposition of the reader; in due course, we might hope, those involved in the emergent application of cognitive science to the Bible might offer studies of this kind.

Rather than simply restate the findings of each section, I conclude by noting the following points, as features of the representation found in Christian scripture. First, intellectual humility is not reducible to a single, simple definition, but is a complex or multipartite concept associated with the cognition of someone who is humble. This complex notion of humility has different constituent elements that might appear separately or together in the lives of humble persons. This recognizes that while one strand of humility involves a recognition of our sinfulness and capacity to know things badly or idolatrously, another strand involves the acknowledgement of dependency upon God, and another strand — which may be associated with God himself-involves a simple willingness to set aside one's own prerogatives in order to pursue the good of others. The strands may appear together, but will not always do so. Second, the lexicon of humility foregrounds the positional associations of the word groups, which designate poverty or lowness, but it does so in a distinctively relational way. It is good to be humble, not because it is good to be poor in itself, but because it is good to acknowledge one's dependency upon God's providence; it is good to be humble, not because there is anything intrinsically good about the posture of bowing, but because it is good to yield to the rule of God in one's life. Third, insofar as Christians cherish intellectual humility, it is not as something that they can foster from within themselves, but something they derive from the presence of another within them. I no longer live, but Christ lives in me; because of that, I know things differently.

Bibliography:

Barclay, John. G. 2015. Paul and the Gift. Grand Rapids, Eerdmans.

Chauvet, Louis-Marie, 1995. Symbol and Sacrament: A Sacramental Reinterpretation of Christian Existence. Trans. P. Madigan and M.E. Beaumont. Collegeville: Liturgical Press.

Church, I. M. and P. L. Samuelson, 2017. Intellectual Humility: An Introduction to the Philosophy and Science. London: Bloomsbury 
Greco, J., 2010. Achieving Knowledge: A Virtue-Theoretic Account of Epistemic Normativity. Cambridge: Cambridge University Press

Macaskill, Grant. 2019. The New Testament and Intellectual Humility. Oxford: Oxford University Press.

Roberts, R. C. and W. J. Wood, 2007. Intellectual Virtues: An Essay in Regulative Epistemology. Oxford: Oxford University Press.

Whitcomb, Dennis, Heather Battaly, Jason Baehr, Daniel Howard-Snyder, 2015. 'Intellectual Humility: Owning our limitations', Philosophy and Phenomenological Research 91, 1-31 